\title{
PRE-SERVICE TEACHING PROGRAM FOR EDUCATING STUDENT- TEACHERS IN MANAGING THEIR CLASS
}

\author{
Titis Sulistyowati ${ }^{\bowtie}$, dan Diah Kurniati
}

English Education Department, FKIP, Universitas Muria Kudus

\section{Info Artikel Abstract}

Sejarah Artikel:

Diterima 19 Okt 2017

Disetujui 31 Okt 2017

Dipublikasikan Des 2017

\section{Keywords:}

student-teachers,

classroom management

pre-service teaching

program
This article presents the finding of a study that investigate pre-service English teacher in managing the class when they were teaching in teaching practice program or Pre-Service Teaching Program. Teaching in a real class is a new experience for the students of Muria Kudus University; however they need to adjust themselves to the teaching environment. They need to prepare some educational knowledge like; classroom management, educational psychology, curriculum development, teaching method etc, in order to be able to organize the lesson well and achieve maximum result. The key of a successful learning is depended on the way teacher organizing the class. In other word the key of a successful language teaching is classroom management. However each class has different characteristics, so a teacher needs to prepare himself to the students' learning style. Maintaining discipline and organizing students can be very frustrating for the student-teachers because they do not only need well understanding about classroom management but they also need to control their performance. The students- teacher or teacher candidates need guidance either from the school teachers or their lecturers; therefore it is also very important to observe their activities in the class to know the improvements which have been done by the teacher.

\begin{abstract}
Abstrak
Artikel ini membahas tentang temuan hasil penelitian yang menginvestigasi guru-guru praktikan PPL dalam pengatuaran kelas selama mereka melaksanakan praktik mengajar PPL (Program Pengalaman Lapangan). Mengajar dalam kelas sesungguhnya merupakan pengalaman baru bagi mahasiswa Universitas Muria Kudus; sehingga mereka perlu menyesuaikan diri dengan lingkungan tempat mereka mengajar. Mereka perlu mempersiapkan pengetahuan kependidikan, seperti; managemen kelas, psychologi kependidikan, pengembangan kurikulum, metode pembelajaran, dan lain lain, agar dapat mengorganisasi pembelajaran dengan baik dan mencapai hasil maksimal. Kunci keberhasilan dari sebuah pembejaran tergantung pada bagaimana cara guru mengorganisasi kelas. Dalam kata lain kunci keberhasilan pembelajaran bahasa adalah managemen kelas. Namun setiap kelas mempunyai karakteristik yang berbeda, sehingga seorang guru perlu mempersiapkan diri dengan gaya belajar siswa. Menegakkan kedisiplinan dan mengorganisasi siswa bisa jadi sangat melelahkan bagi mahasiswa-guru karena mereka tidak hanya perlu memahami tentang managemen kelas dengan baik, tetapi mereka juga perlu mengontrol penampilan. Mahasiswa-guru atau calon guru memerlukan pembimbingan baik dari guru sekolah maupun dari dosen pembimbing; untuk itu sangatlah penting melakukan observasi aktivitas mereka di dalam kelas guna mengetahui peningkatan yang sudah dilakukan mahasiswaguru.
\end{abstract}

(C) 2017 Universitas Muria Kudus
p-ISSN 2087-9385

e-ISSN 2528-696X

Program Studi Pendidikan Guru Sekolah Dasar

Fakultas Keguruan dan Ilmu Pendidikan Universitas Muria Kudus

Kampus UMK Gondangmanis, Bae Kudus Gd. L. 1t I PO. BOX 53

Kudus

Tlp (0291) 438229 ex.147 Fax. (0291) 437198

E-mail: titis.sulistyowati@umk.ac.id 


\section{BACKGROUND}

As teacher candidates, the English education department students need to take Teacher training program as part of pre service English teacher. This program is aimed to provide valuable teaching experience for the students. In this program the students will have a chance to implement their knowledge.

Before deputing the students to the school, the department prepares the students by teaching them some knowledge relating to language teaching. It is the responsible of the teacher training department to train the students before they teach in real class situation. They need to acknowledge, some theories deal with managing the class in micro teaching, the psychology of education and others. Teaching practice program deals with enhancing the student teachers' skill in teaching as well as improving their knowledge though the application at real schools under the department supervision.

In Muria Kudus University, the usual procedures in applying teaching practice program begin with selecting the schools as the teaching laboratory, student teacher supervision and system of assessment. The department and the school work collaboratively to supervise the student teachers to manage their improvement in teaching and to provide accurate assessment for the students. Some lecturers are assigned to monitor the teaching practice and the class teacher supervises the student teachers during the lesson.

Griffiths and Ashcroft (1989), Newmen (1996) and Zbikowsky (1990) as quoted by Letho (2001) believe that to develop an effective teaching, the students as teachers should constantly reflect themselves in the way of teaching. They should consider the teaching purposes, method of teaching that is applied, and the important of learners' behavior. They need to interpret what is going on with the learners mentally, psychologically and socially as they are learning in the classroom and use as the evidence to support and decide the next strategy to be applied to manage the class.

The success of teaching and learning depend on the way the teacher organize the lesson. McCreary (2008) esates 'Classroom management is defined as the methods and strategies an educator uses to maintain a classroom environment that is conducive to student success and learning'.

Hedge (2011: 293) divines 'classroom management is also a key issue given the complex structure of some communication activities.' Classroom management is a complex way of communication between students and teachers, and among students. Harmer (2007) supports that the way we talk to the students, our voice, body movement, are also the key in successful classroom management.

As the teacher candidates, the English education department students of Muria Kudus University need to master the key aspecst of managing the class. The teaching practice program is the momentum when they need to implement their knowledge and at the same time learning how to manage the real complex situation in class. This paper focuses on observing how the student teachers manage their class and improve themselves in maintaining the lesson.

\section{CLASSROOM MANGEMENT}

According to Sejathi in Muliani management means managing, coordinating, and organizing any resources effectively in order to achieve maximum target. Classroom management covers many aspects in teaching and learning process. Harmer (2007: 34) explains the scope of classroom management. 'It includes how the classroom space is organized, whether the students are working on their own or in groups and how teachers organize classroom time. Teachers also need to consider how the teachers appear to the students and how the voice is used-the way teachers talk and communicate with the students. Those are valuable aspect in classroom management issue.'

Brown (2001: 192-202) states that classroom management deals with many factors; ranging from physical arrangement of the classroom to teaching styles to set classroom energy. The physical environment of the classroom include sight, sound and comfort, seating arrangement and the use of classroom equipments. Other aspect is teachers' roles and styles. In class, teachers have to play many roles. In the class, teachers have responsibility as authority figures, leaders, knower, directors, managers, counselors, guides, friends and also parents. Teachers need to set appropriate styles in the class, whether he needs to be formal or informal, rational or emotional, depends on the class situation.

Evertson and Weinstein (2006) as quoted by Korpershoek (2014) implies their definition on classroom management to the actions teachers take to create a supportive environment for the academic and social emotional learning of students. They describe five types of actions. In order to attain a high quality of classroom management, teachers must (1) develop caring, supportive relationships with and among students 
and (2) organize and implement instruction in ways that optimize students' access to learning, (3) encourage students' engagement in academic tasks, which can be done by using group management methods. Teachers must (4) promote the development of students' social skills and self-regulation. Teacher should (5) use appropriate interventions to assist students with behavior problems.

\section{THE PHYSICAL ENVIRONMENT}

The physical environment aspect in classroom management refers to the condition of the classroom. A teacher should be able to create and set the classroom base on the teaching purposes. He/she must maximize the use of class equipment to support the learning process. Brown (2001) categorized some dominant aspects in the classroom. Sight can be a very significance aspect in learning. The classroom that is neat, clean and well arranged will create comfort for the students. Enough light will enable the students to see and read the material well. A good classroom should be free from the external noise as possible; intolerable noise could destruct the students' concentration.

In Indonesia, the sitting arrangements are usually set in rows. This kind of sitting arrangement might not be very effective during the lesson, because the students sometimes need to work in group. In this case teacher need to rearrange the groups depend on the purpose. Harmer (2007: 42-43) states that orderly rows works very well when the teacher is working with the whole class. Some activities are suitable in this organization such as explaining a grammar point, or watching DVD or power point presentation. If teachers want to set group works, it is necessary to change the seating arrangement to create chances for the students to see each other in order to enable them to interact.

Brown (2001: 194) also explains that the use of classroom equipments also determine the success of teaching and learning. A block of chalk/whiteboard is a great asset in the classroom. It allows teacher to illustrate the teaching materials by using pictures, words, charts, graphs etc. In a more modern classroom, some additional equipment might be also found. Projector, video player, or even a set of computer are valuable equipments to support and varied the learning process.

\section{TEACHERS' ROLE}

Teachers are the main factor in managing the class. They are the manager, the director, and they are the main actors who are in charged. Teachers are assets in the class. Their voice, the ways they speak have a crucial impact on classes. Teachers must speak clearly, they must be sure that the students at the back of the class can hear them. They should maintain their voice. Speaking too softly or unpleasantly loudly are irritating (Harmer, 2007: 36). Brown (2001:195) states that in the class where the students do not have all skill to comprehend verbal language, they attention is drown to non verbal communication, body language. Body posture and face expression should reflect optimism, warmth and confidence which shows encouragement to the students to motivate them.

The role that teachers develop in class should concern to the students' comfort and joy to create pleasant atmosphere in the class. Teachers should not intimidate the students; therefore they need to build up students' rapport. Brown (2001: 203) suggests some ways in building the rapport. Teachers need to:

1. Show interest and appreciate to everyone's progress.

2. Solicit students ideas and feeling

3. Work with them as team

4. Respect to the student think and say

5. Develop a genuine sense of joy when they learn something.

\section{PRE-SERVICE TEACHING FOR TEACHER}

Teaching practice is the main concern in teacher training program. It provides opportunities for teacher candidate to expose the resources in the class to support their performance. Bhargava (2009) states 'The teachers training program is not about giving theoretical knowledge of various theories of teaching learning or skills used in the classroom teaching only; rather this should serve as worthwhile experience in making of an inspiring teacher'.

Teaching practice program is a great opportunity for the English education department students to improve their teaching skill. It is not only giving the students knowledge about education but it more concerns on giving the students experience about managing the classroom to prepare them to be professional teachers.

However teaching practice can be a terrorizing moment for student teachers. Teaching practice sometimes becomes a demoralizing and sometimes very frightening experience. This is the moment when the student-teachers should be able to manage class with many students. Being the manager, the focus of attention, and the master in the crowd of students will be a huge problem for some people, 
therefore the student-teachers must be able to manage themselves and be confident.

According to Harmer (2001:24) "good teacher are born, not made and it does seem that some people have a natural affinity for the job, but there are also others, perhaps, who do not have what appears to be a natural gift but who are still effective and popular teacher. Such teachers learn their craft through a mixture of personality, intelligence, knowledge and experience ".

\section{METHODOLOGY}

This study was a case study focuses on observing the class that was managed by the English education department students of Muria Kudus University in Pre-service teaching program. The location of the teaching practice program was at SMP 1 Jati Kudus.

Teaching practice is an opportunity for the student teachers to practice all the knowledge and theories in learning through classroom management, by administrating and controlling their own class. In teaching practice, some problems need to be encountered by the students; therefore they need to do some preparations such as documents, mental preparations, aspect like knowledge, personality, language model, selfconfident, and the learning material.

In this research, two student-teachers were observed when they were teaching. Two different classes are chosen, they were 7A class and $7 \mathrm{~B}$ class. Class $7 \mathrm{~A}$ was a class where the students are considered as smart and active. The students were having higher English competence than 7B class. 7B was a class where the students' achievement is still low. They still needed more motivation and teachers' intensive guidance in learning.

\section{FINDING AND DISCUSSION}

In this section the finding of the research will be discussed. It represents the lesson design and the class management. The lesson design explains about the basic competence, and the aims of the lesson. The class management tells the process of the teaching and learning done by the student-teachers.

\section{THE LESSON DESIGN}

Before going to the classroom for teaching practice, the teacher candidates need to plan their lesson. Hedge (2007: 338-349) explains that there are many aspects need to be considered in designing lesson plan. Teachers need to establish the appropriate steps in teaching, including time allocation; they also need to decide the goals and objective. Planning the most effective lessons takes time, diligence, and an understanding of your students' goals and abilities. The goal, as with all teaching, is to motivate the students to take in what you are teaching and to retain as much as possible.

The student-teachers' lesson plan usually consist of standard competence, teaching material, goal, teaching method and the steps of teaching. Teaching competence tells the learning competences that need to be achieved. Reading; explaining the meaning served in written functional text in form of announcement to interact in social environment, which can be elaborated into basic competence; explaining the strands of meaning in short functional text by using variety of language which is accurate, fluent and acceptable to communicate in social environment in form of announcement. The learning objectives are; the students can complete the information, arranging the sentences and write announcement.

Writing; explaining meaning in simple short functional text to interact with the social surrounding, this is completed by some basic competences; to explain the rhetorical structure and to use various written language that is accurate, fluent and acceptable.

Speaking; explaining short functional text and monologue orally to interact with the social surroundings. This is also completed with basic competence; to explain the stand of meaning served in simple short functional text and monologue.

Listening; understanding short functional text in order to be able to interact with social surrounding, which can be elaborated as; responding various speech act in simple spoken short functional text accurately, fluently and acceptable in order to interact with their social surrounding.

\section{THE CLASS MANAGEMENT Apperception}

The student- teacher begins the lesson by doing apperceptions. He/she greets the students and asks their activities in few days before. This activity is important to build up students' rapport and create warm atmosphere in the classroom. It is also can encourage students' motivation in learning as it will provide relaxation and enjoyment for the students. It is also good for apperception since the student-teachers can connect their activities with the learning material. This strategy will directly connect the language learning to the language use in context.

To connect the material to the students' daily life, the student-teachers explain the purpose of the learning. Mentioning the list of 
the goods that the students meet in the grocery stores is very useful for explaining short functional text on 'Shopping List'. This will give the students understanding on the reason why they need a shopping list before they go for shopping. This will also add the students' vocabularies on items at stores. Making list of things that the students find at home is also good activities to connect the materials to the real life language. Home is the nearest students' social environment where they usually spend most of their time with family and friends.

The student-teachers sometimes also use questioning strategy to give warming up to the students. In some cases, questioning strategy is very effective to stimulate the students' curiosity about the learning material, but teacher need to be aware whether the students feel like being tested, because for some students, test is quite terrorizing and it will destroy the enjoyment. Therefore the student teachers need to focus only on the simple questions.

In apperception, student-teachers also playing music or songs which directly connected to the material being discussed. Playing song for giving apperception on congratulating people is a good way for giving example how people do to appreciate people, since there are many ways to congratulate others. Music will motive the students, it gives enjoyment and relaxation. Moreover it stimulates the right brain to process language learning.

\section{Main activity}

In main activity, student-teachers use three steps; they are exploration, elaboration, and confirmation.

The first step is Exploration. In this step, student-teachers try to give some prior knowledge about the teaching material. They explore texts and the details generic structures. They get the students into deep understanding about texts by discussion and questioning.

In Elaboration, students connect the information they have to connect it with the learning material they have. It is because elaboration strategy connects the information the students already have to the information they learn in this case students need to expand their knowledge. Because elaboration strategies create connections, or bridges, to information to be learned, they can be powerful instructional tools for a classroom. The confidence that students have in already knowing the connected information can support their learning of new information. In this section, the student-teachers divide the students into groups. They lead the students to works together and rais the team work tension by giving games. Teacher uses greeting card for teaching aids to help to explain about 'greeting and congratulation'.

However the students of English education department still need to learn more how to organize the students especially in group works. When the students are working in groups, the class can be very crowded and noisy. In this kind of situation, the student-teachers should acknowledge some techniques in controlling them and know how to get the students' attention back.

The final step is confirming. Confirming means to check the students' understanding on the learning materials. Here, student-teachers give feedback on the students' works. They give more explanation on the set of materials. Students are given open chances to deliver questions and comments. 'Concept checking is normally achieved by the use of a set of questions designed to ensure comprehension of the target language, raise awareness of its problems, and to indicate to the teacher that the learners have fully understood.'

In Explaining the learning material, the student-teachers use English, in some occasions, they also use Indonesian to give more explanation to the students. It is because the students' English level is still beginner; therefore Indonesian is needed to make sure that they really understand the explanation. Simple English is used to explain and give examples. The student-teachers also use media in explaining the material. Pictures are used to attract the students because students are easily capture images, because it provides colors and it can represent real objects. Student-teachers usually make the pictures and combine it with mind mapping technique. They also sometimes use flash cards.

Building a rapport with students can make the difference when teaching, especially in a second language. It is useful for creating good atmosphere in the class. A teacher is not only teaching but they need to be close and intimate with the students. They can be friends, advisor, guardians, and perhaps parents. To build up the comfort of the students, students- teacher often walk around and guide them personally. It indicates that the teacher pay attention to the individual achievement. It is also important for the student teacher to be very open and show willingness to respond every student's question and critics wisely.

\section{Closing}

Closure is the time when teacher end up a lesson plan and help students organize the information into a meaningful concept in their 
minds. It is very important for the studentteacher to make a brief summary or overview about the lesson often appropriate. Another helpful activity is to engage students to the lesson by giving them some assignment to do at home.

Todd (2015) implies that teachers can use some activities in closure. Checking for understanding and inform subsequent instruction is very crucial in closing. Teacher also needs to emphasize key information, tie up loose ends and correct misunderstandings. Closing is also very useful for students. They need to Summarize, review, and demonstrate their understanding of major points. They need consolidating and internalizing key information. They have to link lesson ideas to a conceptual framework and/or previously-learned knowledge and to transfer ideas to new situations.

\section{CONCLUSION}

Pre-service teaching program is the main focus on teacher training program. It offers the opportunity to bring theories to the practice in preparing the candidate teachers in a real classroom setting. Teaching is also a process of learning for the student-teachers; therefore they still need intensive guidance from both the school supervisors and their lecturers. The students as the next teachers are expected to be professional teachers, therefore it is very essential from them to be able to manage the lesson and the students well. Maintaining the students, deals with establishing the discipline. The classroom management becomes difficult if student teachers are not able to get along with children well. In this case the student-teachers should be aware of establishing teachers' roles in the class.

Many aspects need to be improved on the way the student-teachers manage the class. They need to do some reflective teaching after the lesson in order to enhance the quality of the learning process. Variation on the learning technique is needed to give students more experience with more learning materials. Sometimes teacher need to highlight the most important aspect in learning, such as key words and main ideas. This technique will give the students hints to remember the information they have learnt.

\section{REFERENCES}

Bhargava, Anupama. 2009. Teaching Practice For Student Teachers Of B.Ed Programme: Issues, Predicaments \& Suggestions. Turkish Online Journal of Distance Education-TOJDE 10 (2).
Brown, H. Douglas. 2001. Teaching by Principles: An Interactive Approach to Language Pedagogy. New York: Longman.

Finley, Todd . 2015. 22 Powerful Closure Activities. https://www.edutopia.org /blog/22- powerful-closure-activitiestodd-finley accessed at 15 th Oktober 2017.

Harmer, Jeremy. 2007. How to Teach English. Edinburg Gate: Longman.

Harmer, Jeremy. 2007. The Practice of English Language Teaching. Edinburg Gate: Longman.

Hedge, Tricia. 2007. Teaching and Learning in The Language Classroom. China: Oxford University Press.

Korpershoek, Hanke et all. 2014. Effective classroom management strategies and classroom management programs for educational practice. University of Gronigen

http://www.rug.nl/research/portal/files/15 665813/PDF_GION_rapport_Effective_C lassroom_Management.pdf accessed 15th Oktober 2017.

Letho, Thabo Samuel. 2001. An Effective Teaching practice program http ://spectrum.library.concordia.ca/1464/1/M Q82665.pdf accessed at 10th November 2013.

McCreary, Randy. Classroom Management Definition.

http://classroom.synonym.com/classroommanagement-definition-

5438989.html\#ixzz2jIk9pTIG . accessed at 16 Oktober 2017.

Elaboration strategies. http://www.specialconnections.ku.edu/?q $=$ instruction/cognitive_strategies/teacher_to ols/elaboration_strategies accessed at $1 \overline{5}$ th Oktober 2017.

Checking Understanding https://www.teachingenglish.org.uk/articl e/ checking-understanding accessed at $15^{\text {th }} \quad$ Oktober 2017. 